\title{
Relationship of Stock Price and Monetary Variables of Asian Small Open Emerging Economy: Evidence from Thailand
}

\author{
Nararuk Boonyanam ${ }^{1}$ \\ ${ }^{1}$ Faculty of Economics at Si-Racha, Kasetsart University, Chonburi, Thailand \\ Correspondence: Nararuk Boonyanam, Faculty of Economics at Si-Racha, Kasetsart University, Chonburi, Thailand. \\ E-mail: noaratc@gmail.com
}

Received: October 17, 2013

Accepted: October 30, $2013 \quad$ Online Published: January 10, 2014

doi:10.5430/ijfr.v5n1p52

URL: http://dx.doi.org/10.5430/ijfr.v5n1p52

\begin{abstract}
Monetary variables contain information to forecast stock price is still controversial. This paper examines the relationship between stock price and monetary variables in Thailand which is an Asian small open emerging economy. Monetary variables are consumer price index, nominal bilateral exchange rate in term of bath per US dollar, narrow money, and 14 days repurchased rate, employing a multivariate cointegration, VECM, variance decomposition and impulse response analysis covering the period of January 1999 to December 2012 with 168 observations. The study found a long run relationship between monetary variables and stock price. There is no short run adjustment toward the long run equilibrium but narrow money and interest rate have significant short run effect on stock price. The bidirectional causality between stock price and inflation and between stock price and narrow money are found. A unidirectional causality is found from exchange rate to stock price and from interest rate to stock price. Variance decomposition indicates that narrow money and the interest rate contribute the highest in stock price while the variance in stock price give the highest contribution to exchange rate, narrow money and inflation respectively. The impulse response analysis indicates that the stock price responses intensively to narrow money and interest rate. The monetary variables response to the shock in stock price intensively after 2 months and all responses appear to divert away along the horizon which confirms the VECM result that there is no short-run adjustment towards the long run equilibrium. The relationship facilitates investor and policy maker in making effective investment decision as well as the efficient policy designation.
\end{abstract}

Keywords: stock price, menetary variable, stock exchange of Thailand, cointegration

\section{Introduction}

The notion that monetary variables contain information to forecast stock price is still controversial. Theoretically, the stock valuation model suggests that stock prices should reflect investors' expectations of future real economic activity. The fundamental value of a firm's stock will equal the expected present value of the firm's future cash flow and future cash flow are based on the expected performance of the firms where the performance of the firm is influenced by changing patterns in monetary variables through the future cash flow or the risk adjusted discount rate in the model. Therefore, any innovation in monetary variables will affect the firm profit and consequently the asset price. If an asset pricing mechanism is efficient and reflects the fundamentals of the firm, then the stock prices can serve as a leading indicator of real activity.

There are a large number of empirical investigations on the relationship between macroeconomics variables and stock price in the developed economies. These macroeconomics variables are the combination of variables in goods market and money market. However, this relationship is less known in small open emerging market economies especially the study of the relationship between the stock price and variable in money market which justify the need of a more study on this topic in those countries. Cheng and $\mathrm{Ng}$ (1998) find a long-run co-movements between stock price and aggregate economic activity in the United States, Canada, Germany, Italy, and Japan. Sim and Maysami (2000) examine the dynamic relations between macroeconomic variables and the Singapore stock market as well as between the US and Japanese stock markets, and the Singapore stock market. The study finds a cointegration relationship between changes in Singapore stock market and macroeconomic variable and between the Singapore, US and Japanese stock market. Binswanger (2003) find that the strong relationship between stock return and real activity in the G-7 countries (Canada, France, Germany, Italy, Japan, U.K) has disappeared during the 1980s which 
suggest the emergence of a speculative bubble in these countries. Janor et al. (2005) investigate the relationship of stock market and economic activity in Malaysia. They find that the stock market lead changes in economic activity but there is no relation in sub-periods which indicate that the stock market as a predictor to economic activity is sensitive to different stock market conditions. Garza-Garcia et al. (2010) find that Shanghai Composite Index is a leading indicator for macroeconomic variables and the US stock index is related to the Chinese stock index performance. Habibullah and Baharumshah (1996) examine the relationship between the macroeconomic variables and the stock price in Malaysia. The study results showed that the growth of money supply and national output can be used as a trading rule to predict stock prices. Herve et al. (2011) investigate a long run relationship between macroeconomic variables and stock prices in Cote d' Ivoire. They find that the key determinants of the stock price movement are the monetary variables namely consumer price index and domestic interest rate. In addition the variables in goods market are not appropriate indicators to forecast the future stock index movement. Hosseini et al. (2011) study the role of four macroeconomic variables which are the crude oil price, money supply, industrial production and inflation rate on stock market index in China and India employing Johanse-Juselius multivariate cointegration and Vector eroor correction model technique. The study found a short run and long run linkage between macroeconomics variable and stock market index in both countries.

Thailand is one of Asian emerging economy. The stock exchange of Thailand has shown a tremendous growth after the 1997 financial crisis: The SET index rose from 363 index point in January 1999 to 1,391.93 in December 2012. This rapid growth has attracted the foreign investors both in the goods market and money market. The objective of this paper is to provide an example of the relationship of monetary variables and stock price in an Asian small open emerging economy by evaluating the notion that monetary variables contain information to forecast stock price using a multivariate framework. There are some studies on this relationship in Thailand but mostly in the goods market or a combination of the goods market and money market. Wongbangpo and Sharma (2002) study stock market and macroeconomic fundamental dynamic interaction: ASEAN-5. The macroeconomic variables used are GNP, consumer price index, money supply, interest rate and exchange rate. The study finds that in the long run, stock prices are positively related to growth in output, and negatively to the aggregate price level. A negative long run relationship between stock prices and interest rate is found in Philippines, Singapore and Thailand while the positive relationship is found in Indonesia and Malaysia. High inflation in Indonesia and Philippine leads to a long run negative relationship between stock prices and the money supply, while the money growth in Malaysia, Singapore and Thailand causes a positive effect on their stock market indices. Exchange rate is positively related to stock price in Indonesia, Malaysia and Philippine but negatively in Singapore and Thailand. The ASEAN 5 stock market interact with their own key macroeconomic factor. Mansor et al. (2009) study the long-run relationship and dynamic interaction between housing and stock price in Thailand employing an Autoregressive distributive lags (ARDL) cointegration test and impulse response function. The variables used are in real term and the result is in line with conventional views that stock price shock effect real economic activity. Tangjitprom (2012) study the macroeconomic factors that determine the stock market performance in Thailand employing regression analysis based on the Arbitrage Pricing Theory (APT), and examine the lead-lag relationship using Vector Autoregression model and Granger causality test. The study result is in line with the Bank of Thailand's report that the SET index is the leading economic indicator of macroeconomic factors. Jiranyakul (2012) examine the relationship between exchange rate and stock market index in a bivariate framework during the period of the floating exchange rate regime in Thailand. He finds that there is no long-run relationship between stock prices and exchange rate. However, there exists positive unidirectional causality from stock market return to exchange rate return which indicates that the exchange rate risk causes stock return to fall, and a bidirectional causal relation between stock market risk and exchange rate risk is found. Chokesirikulchai et al. (2013) investigate the relationship of macroeconomic factors, SET index, and SET property development index using multiple regression analysis and t-test. The macroeconomic variables used are exchange rate, interest rate and inflation rate. The study finds that there is relationship between stock market, property stock market, and macroeconomic variables. The interest rate has the highest predictive power over the rest variables for SET index where inflation has the highest predictive power for the property index. This paper will be concentrated only on the money market. Money market is the financial markets for assets involved in short-term borrowing, lending, buying and selling with original maturities of one year or less. The variables used are in nominal term which reflects the current situation better than the variable in real term. Theoritically, financial market in an open economy where there is a free flow of capital, is efficient. Detection of relationship between stock price and monetary variables holds implication for investors on the efficiency of the financial market in Thailand and other Asian small open emerging economies.

The rest of the paper is organized as follow. Section 2 discusses the data and methodology employed for this study, 
Section 3 presents the empirical result and section 4 is the conclusion of this study.

\section{Method}

The monthly data used in this study are the stock market index from the Stock Exchange of Thailand (SET), consumer price index (CPI) which represent the inflation factor, narrow money (M1) which represent the money quantity, 14 days repurchase rate (REPO) which represent the level of interest rate and nominal bilateral exchange rate in term of bath per U.S. dollar (Forex). The period covers January 1999 to December 2012 with 168 observations. The period used is purposely selected to avoid the financial crisis in 1997 which has a turmoil exchange rate and interest rate. The relationship between stock market return (SET) and the monetary variables (CPI, Forex, M1 and REPO) have been examined by using multivariate cointegration and causality analysis. If the variables are integrated in the same order and cointegrated, the causation is obtained from the vector error correction model. Then, impulse response function and variance decomposition are used to test for the source of volatility.

\subsection{Multivariate Cointegration Test}

The long-run relationship between the stock price and monetary variable is specified as a reduced form VAR of order p:

$$
\mathrm{y}_{\mathrm{t}}=\mathrm{C}+\mathrm{A}_{1} \mathrm{y}_{\mathrm{t}-1}+\ldots+\mathrm{A}_{\mathrm{p}} \mathrm{y}_{\mathrm{t}-\mathrm{p}}+\mathrm{u}_{\mathrm{t}}
$$

where $C$ is a vector of constant term, $y_{t}$ is a k-vector of $I(1)$ variables, and $u_{t}$ is a vector of error term. The VAR(p) model can be rewrite in term of Vector Error-Correction model: VECM(p-1) as:

$$
\begin{gathered}
\Delta \mathrm{y}_{\mathrm{t}}=\mathrm{C}+\prod_{\mathrm{t}-1}+\sum_{i=1}^{p-1} \mathrm{ri} \Delta y t-i+u t \\
\text { Where } \Pi=\sum_{i=1}^{p} A i-I, \Pi_{\mathrm{i}}=-\sum_{j=i+1}^{p} A j
\end{gathered}
$$

The $\Pi$ matrix indicates the adjustment to disequilibrium following an exogenous shock. If $\Pi$ has reduced rank $\mathrm{r}<\mathrm{k}$ where $\mathrm{r}$ and $\mathrm{k}$ indicate the rank of $\Pi$ and the number of variable respectively, then there exists two $\mathrm{k} \mathrm{x} \mathrm{r}$ matrices $\alpha$ and $\beta$, each with rank $\mathrm{r}$, such that $\Pi=\alpha \beta^{\prime}$ and $\beta^{\prime} y_{\mathrm{t}}$ is stationary. The cointegration rank is given by $\mathrm{r}$ and each column of $\beta$ is cointegrating vector showing a long run relationship. The element of the $\alpha$ matrix represent the adjustment coefficients giving the speed of adjustment of endogenous variables in response to shock. The element of the $\beta$ matrices indicates the short run dynamic adjustment. The test procedure relies on relationships between the rank of a matrix and its characteristic roots or eigenvalues. The rank of $\beta$ equals the number of its characteristic roots that differ from zero, which corresponds to the number of cointegrating vectors. The maximum eigenvalue test statistics and trace test statistics are used to determine the number of cointegrating vector.

\subsection{Vector Error Correction Model (VECM)}

A vector error correction model (VECM) is a restricted VAR that has cointegration restrictions built into the specification. The error correction model is based on the following equation:

$$
\Delta \mathrm{y}_{\mathrm{t}}=\beta_{0}+\beta_{1} \mathrm{e}_{\mathrm{t}-1}+\sum_{i=1}^{m} \beta i \Delta y t-i+\varepsilon_{\mathrm{t}}
$$

Where $e_{t-1}$ is the error correction term lagged one period obtained from the cointegration equation which will capture the speed of the short run adjustments towards the long run equilibrium.

\subsection{Block Exogeneity Test}

Granger (1988) noted that there are two ways to obtain the causality from VECM; bottom up approach and top down approach. The bottom up approach, Wald test is applied to examine whether knowing the current and lagged values of $\mathrm{x}$, besides all other available information, improves the forecasts of the future values of $\mathrm{y}$. For example to test whether $\mathrm{X}$ Granger causes $\mathrm{Y}$ a Wald test is used to test whether all the lagged values of $\mathrm{X}$ in the $\mathrm{Y}$ equation are simultaneously equal to zero. $\mathrm{X}$ Granger causes $\mathrm{Y}$ if $\Sigma \beta \neq 0$ and, if both $\Sigma \delta \neq 0$ and $\Sigma \beta \neq 0$, then there exists a bidirectional causality between $\mathrm{Y}$ and $\mathrm{X}$. In another word, we use a Wald test to find the joint significance of past variable in explaining current variable in a VECM model. The top down approach use the consequential Wald test to find the causality relationship between variable by applying Block Exogeneity test. This method is more appropriate in multivariate framework analysis. Therefore in this study, the top down approach, Block exogeneity test is employed.

\subsection{Impulse Response Function}

Most paper conducts the impulse response function (IRF) from the VAR equations which its series are nonstationary in levels. However the analysis of IRF of this study will be obtained from the VECM as a Monte-Carlo experiments found that the long run structure for impulse response analysis in VAR models is important. There can be a 
substantial biases involved in estimating VAR models in levels if there is in fact cointegration. These biases are important at the short horizon, as well as the long run. They can affect economic inference drawn from the estimated impulse response functions; in fact "puzzles" can appear when there are in fact none. Therefore, in contrast to common practice, before identifying and estimating any economic shock, researchers should analyse the cointegrating properties of the data and restrict the VAR (i.e. estimate a reduced rank VAR, a vector error correction model) when the data are cointegrated as taking cointegration into account is more accurate than ignoring it and estimating a VAR in levels (Note 1).

\subsection{Variance Decomposition}

Variance decomposition shows the fraction of the h-step ahead forecast error in $\mathrm{y}_{\mathrm{i}, \mathrm{t}}$ attributed to its own innovations $\left(\varepsilon_{\mathrm{i}, \mathrm{t}}\right)$ and innovations in other variable $\left(\varepsilon_{\mathrm{j}, \mathrm{t}}\right)$, which imply the relative importance of each innovation in affecting the forecast error of variables in the VAR or VECM

\section{Results}

Before analyzing the relationship between the stock price and the monetary variables, all data are transformed into logarithmic series. The correlation matrix is presented in Table 1.

The positive correlation between Consumer price index (LNCPI) and Stock price (LNSET) is in line with Fisher's hypothesis.

The negative correlation between stock price (LNSET) and the exchange rate (LNFOREX) is in line with the theory that the currency depreciation will have a positive impact on a domestic stock market. As Thai currency depreciate against the U.S. dollar, the products exported from Thailand become cheaper in the world market. As a result, if the demand for these goods is elastic, the volume of exports from these countries should increase, which in turn cause higher cash flow, profits and the stock price.

The positive correlation between Narrow money (LNM1) and Stock price (LNSET) is in line with the theory that an increase in money supply leads to an increase in liquidity and lead to an increasing stock market investment. In another word, an increase in the money supply creates an excess supply of money balances and an excess demand for equity, and results in an increase in equity prices.

The positive correlation between the stock price (SET) and 14 day repurchased rate (LNREPO) is contradicted to the theory. Normally, an increase in interest rate negatively affect the stock market as one method of valuing a company is to take the sum of all the expected future cash flows from that company discounted back to the present. Higher discounted rate will lead to a price reduction. In addition, the consumer behavior will change, when the interest rate is higher, the consumer will convert their investment from the stock market to bond market resulting in a drop in stock market investment.

Since the correlation analysisis a weak technique, therefore the Multivariate cointegration analysis is employed to investigate the long-run relationship between the stock price and monetary variables.

Table 1. Correlation matrix

\begin{tabular}{llllll}
\hline & LNCPI & LNFOREX & LNM1 & LNREPO & LNSET \\
\hline NCPI & 1 & -0.884186 & 0.963661 & 0.360743 & 0.842049 \\
LNFOREX & 1 & -0.810316 & -0.261622 & -0.811187 \\
LNM1 & & 1 & 0.292139 & 0.876424 \\
LNREPO & & & 1 & 0.34805 \\
LNSET & & & & 1 \\
\hline
\end{tabular}

The first step is to test for the unit root. The Augmented Dickey-Fuller (ADF) and Phillips and Perron (PP) test with an intercept only and an intercept and a trend are used to test for unit root in level and the $1^{\text {st }}$ difference of the series. The optimal lags is chosen by AIC for ADF test and optimal bandwidth for PP test is chosen by Newey-West, Barlett kernel spectral estimation method. The result in Table 2 indicate that the ADF test with intercept only and an intercept and a trend fail to reject the null hypothesis of the existence of a unit root in levels but reject the null hypothesis in the first difference of the series while the PP test provide the same results accept for the LNM1 series with an intercept and a trend that reject the null hypothesis in both level and $1^{\text {st }}$ difference. Thus, all series used in this study are integrated of order $1, \mathrm{I}(1)$. 
Table 2. Unit root analysis

\begin{tabular}{|c|c|c|c|c|}
\hline \multirow[b]{2}{*}{ Variable } & \multicolumn{2}{|c|}{ ADF test - level } & \multicolumn{2}{|c|}{ ADF test - 1st difference } \\
\hline & (intercept) & (intercept + trend $)$ & (intercept) & (intercept + trend $)$ \\
\hline LNSET & $-0.675071[3](0.8488)$ & $-2.840823[3](0.1850)$ & $-12.48098[0](0.000)$ & $-12.45954[0](0.000)$ \\
\hline LNCPI & $0.329109[1](0.9792)$ & $-3.213563[1](0.0853)$ & $-8.955112[0](0.000)$ & $-8.988713[0](0.000)$ \\
\hline LNFOREX & $-0.526941[10](0.8815)$ & $-3.080892[10](0.1145)$ & $-10.95567[0](0.000)$ & $-11.03163[0](0.000)$ \\
\hline LNM1 & $0.073843[13](0.9628)$ & $-1.396909[13](0.8583)$ & $-4.777974[11](0.0001)$ & $-4.703155[11](0.0010)$ \\
\hline LNREPO & $-2.126091[2](0.2348)$ & $-2.336826[12](0.4114)$ & $-8.729364[0](0.000)$ & $-8.743721[0](0.000)$ \\
\hline \multirow{2}{*}{ Variable } & \multicolumn{2}{|c|}{ PP test - level } & \multicolumn{2}{|c|}{ PP test - 1st difference } \\
\hline & (intercept) & (intercept + trend) & (intercept) & (intercept + trend $)$ \\
\hline LNSET & $-0.785952[4](0.8201)$ & $-2.467992[5](0.3436)$ & $-12.53043[4](0.0000)$ & $-12.50778[4](0.0000)$ \\
\hline LNCPI & $0.590925[1](0.9891)$ & $-2.853961[2](0.1804)$ & $-8.940179[4](0.0000)$ & $-8.969269[4](0.0000)$ \\
\hline LNFOREX & $-0.218593[0](0.9324)$ & $-2.897642[2](0.1660)$ & $-10.97679[3](0.0000)$ & $-11.02044[4](0.0000)$ \\
\hline LNM1 & $-0.162511[8](0.9394)$ & $-4.166154[3](0.0062)$ & $-17.49178[6](0.0000)$ & $-17.43442[6](0.0000)$ \\
\hline LNREPO & $-2.221709[7](0.1995)$ & $-2.531173[7](0.3129)$ & $-8.847102[4](0.0000)$ & $-8.876343[4](0.0000)$ \\
\hline
\end{tabular}

Notes: The number in brackets is the optimal lag length determined by AIC for ADF test and the optimal bandwidth determined by the Bartlett kernel for the PP test, the number in parentheses is the p-value provided by MacKinnon (1996)

Table 3 presents the likelihood ratio (LR) tests to determine the lag length of the VAR. The selection of lag order of unrestricted VAR is determined by Akaike information criterion (AIC) and the most appropriated lag length is 2 .

Table 3. VAR lag order selection criteria

\begin{tabular}{lllllll}
\hline Lag & LogL & LR & FPE & AIC & SC & HQ \\
\hline 0 & 535.9592 & NA & $9.02 \mathrm{e}-10$ & -6.63699 & -6.540891 & -6.597968 \\
1 & 1775.765 & 2386.625 & $2.29 \mathrm{e}-16$ & -21.82206 & $-21.24546^{*}$ & $-21.58792^{*}$ \\
2 & 1813.262 & 69.83982 & $1.96 \mathrm{e}-16^{*}$ & $-21.97828^{*}$ & -20.92119 & -21.54903 \\
3 & 1832.381 & 34.41335 & $2.12 \mathrm{e}-16$ & -21.90476 & -20.36718 & -21.2804 \\
4 & 1857.442 & 43.54316 & $2.13 \mathrm{e}-16$ & -21.90552 & -19.88744 & -21.08605 \\
5 & 1875.537 & 30.30942 & $2.33 \mathrm{e}-16$ & -21.81921 & -19.32063 & -20.80463 \\
6 & 1901.288 & $41.52368^{*}$ & $2.34 \mathrm{e}-16$ & -21.8286 & -18.84953 & -20.6189 \\
7 & 1923.129 & 33.85361 & $2.46 \mathrm{e}-16$ & -21.78911 & -18.32954 & -20.3843 \\
8 & 1937.579 & 21.49429 & $2.87 \mathrm{e}-16$ & -21.65724 & -17.71717 & -20.05731 \\
\hline
\end{tabular}

*indicate lag order selected by the criteria

The relationship between the stock price and monetary variable is specified as a reduced form VAR of 2 lag as presented in Table 4. The $\mathrm{R}^{2}$ for each model is high and the Durbin-Watson statistic show that there is no spurious regression as the Durbin-Watson statistic is greater than $\mathrm{R}^{2}$. In addition, there is no autocorrelation problem in the model. This is also confirmed by Serial Correlation LM Tests in Table 7. 
Table 4. Vector autoregression model estimation

\begin{tabular}{|c|c|c|c|c|c|}
\hline & LNSET & LNCPI & LNFOREX & LNM1 & LNREPO \\
\hline \multirow[t]{2}{*}{ LNSET(-1) } & $0.958860 * * *$ & $0.009637^{*}$ & $-0.045821 * *$ & -0.020269 & -0.026256 \\
\hline & [ 10.8058$]$ & [ 1.69702$]$ & {$[-2.38330]$} & {$[-0.50713]$} & {$[-0.29477]$} \\
\hline \multirow[t]{2}{*}{ LNSET(-2) } & 0.002000 & $-0.010952 *$ & $0.038294 *$ & $0.049064 * * *$ & $0.217374 * *$ \\
\hline & {$[0.02217]$} & {$[-1.89730]$} & [ 1.95939$]$ & {$[1.20759]$} & [2.40067] \\
\hline \multirow[t]{2}{*}{ LNCPI(-1) } & 0.099303 & $1.246745^{* * *}$ & 0.266163 & -0.312445 & $3.449478 * * *$ \\
\hline & {$[0.08480]$} & [ 16.6369$]$ & [ 1.04904$]$ & {$[-0.59236]$} & {$[2.93451]$} \\
\hline \multirow[t]{2}{*}{ LNCPI(-2) } & -0.239478 & $-0.333285^{* * *}$ & -0.320369 & 0.661223 & $-2.210068 * *$ \\
\hline & {$[-0.20883]$} & {$[-4.54155]$} & {$[-1.28941]$} & [ 1.28013$]$ & {$[-1.91992]$} \\
\hline \multirow[t]{2}{*}{ LNFOREX(-1) } & 0.258459 & 0.024881 & $0.994450 * * *$ & -0.121424 & 0.192251 \\
\hline & [0.63293] & [0.95213] & [ 11.2398$]$ & {$[-0.66016]$} & {$[0.46901]$} \\
\hline \multirow[t]{2}{*}{ LNFOREX(-2) } & -0.167374 & $-0.049015^{*}$ & -0.063138 & 0.242336 & 0.533090 \\
\hline & {$[-0.40647]$} & {$[-1.86008]$} & {$[-0.70769]$} & [ 1.30658$]$ & [ 1.28970$]$ \\
\hline \multirow[t]{2}{*}{ LNM1(-1) } & $0.562631 * * *$ & $0.027604 * *$ & -0.014311 & $0.685932 * * *$ & $-0.300405^{*}$ \\
\hline & [3.19591] & [2.45021] & {$[-0.37519]$} & [ 8.65032$]$ & {$[-1.69991]$} \\
\hline \multirow[t]{2}{*}{ LNM1(-2) } & $-0.434694 * *$ & -0.005688 & 0.013596 & 0.214983 & -0.020049 \\
\hline & {$[-2.38526]$} & {$[-0.48768]$} & {$[0.34434]$} & {$[2.61901]$} & {$[-0.10959]$} \\
\hline \multirow[t]{2}{*}{ LNREPO(-1) } & $-0.171139 * *$ & 0.002323 & 0.008050 & -0.028497 & $1.130061^{* * *}$ \\
\hline & {$[-2.28306]$} & {$[0.48421]$} & {$[0.49562]$} & {$[-0.84400]$} & [ 15.0182$]$ \\
\hline \multirow[t]{2}{*}{ LNREPO(-2) } & $0.158748^{* *}$ & -0.000884 & -0.008589 & 0.011819 & $-0.216345^{* * *}$ \\
\hline & [ 2.24520$]$ & {$[-0.19546]$} & {$[-0.56069]$} & {$[0.37112]$} & {$[-3.04821]$} \\
\hline \multirow[t]{2}{*}{$\mathrm{C}$} & -1.183805 & $0.182070 * *$ & $0.545978^{* *}$ & -0.797838 & $-4.924347 * * *$ \\
\hline & {$[-1.07500]$} & [ 2.58361$]$ & [ 2.28831] & {$[-1.60850]$} & {$[-4.45477]$} \\
\hline R-squared & 0.970824 & 0.998287 & 0.984142 & 0.991422 & 0.971175 \\
\hline D-W statistic & 1.941222 & 2.051054 & 2.044661 & 1.991128 & 2.056493 \\
\hline
\end{tabular}

Note: the number in bracket is t-statistic

$* * *, * *, *$ significant at level $1 \%, 5 \%, 10 \%$, respectively.

\subsection{Multivariate Cointegration Test}

The max-eigenvalue and trace statistic in multivariate cointegration analysis indicated that there is one cointegration equation at the 0.05 significant level, therefore there exist a long run relationship between monetary variables and stock price in Thailand.

Table 5. Multivariate cointegration analysis

\begin{tabular}{ccc}
\hline Ho & Max-Eigenvalue & Trace Statistic \\
\hline $\mathrm{r}=0$ & $43.46498^{* *}$ & $79.13270^{* *}$ \\
$\mathrm{r} \leq 1$ & 17.86143 & 35.66772 \\
$\mathrm{r} \leq 2$ & 9.334082 & 17.80628 \\
$\mathrm{r} \leq 3$ & 8.394190 & 8.472202 \\
$\mathrm{r} \leq 4$ & 0.078013 & 0.078013
\end{tabular}

Note: $* * *, * *, *$ significant at level $1 \%, 5 \%, 10 \%$, respectively. 
The normalized cointegrating coefficients are presented in table 6. The result indicates that LNFOREX, LNM1 and LNREPO are significant. LNM1 and LNREPO have negative sign which suggest that narrow money and interest rate have inverse relationship with stock price while LNFOREX have positive sign which suggest the positive relationship with the stock price.

The possible explanation of the contradiction result of long run relationship between the narrow money and stock price with the theory is that normally, an increase in the money supply creates an excess supply of money balances and an excess demand for equity, and results in an increase in equity prices. However there can be a negative effect of the money supply on stock price through higher inflation as Praphan and Subhash (2002) found in Indonesia and Philippine that the high inflation leads to a long run negative relationship between stock prices and the money supply.

The positive relationship of exchange rate and stock price is contradicted to the theory, however it is in line with Komain (2012) study.

Table 6. Normalized cointegrating coefficients

\begin{tabular}{lcc}
\hline Dependent variable: LNSET & Coefficient & S.E \\
\hline LNCPI & 9.975126 & 1.33201 \\
LNFOREX & $4.246406^{* *}$ & 0.51233 \\
LNM1 & $-2.711727^{* *}$ & 0.32718 \\
LNREPO & $-0.459849^{* *}$ & 0.07001
\end{tabular}

Diagnostic test for the cointegration model estimation using the Lagrange multiplier test statistic is presented in Table 7. The result indicate that we fail to reject the null hypothesis of no serial correlation up to the lag 2 , therefore there is no serial correlation up to lag 2 in the residual.

Table 7. Residual serial correlation LM tests

\begin{tabular}{ccc}
\hline Lags & LM-Stat & Prob \\
\hline 1 & 36.09092 & 0.0702 \\
2 & 30.48353 & 0.2067 \\
3 & 38.53557 & 0.0410 \\
\hline
\end{tabular}

Probs from chi-square with $25 \mathrm{df}$.

\subsection{Vector Error Correction Model (VECM)}

When the variables are cointegrated, the Vector- Error Correction Model (VECM) that describes the short-run dynamics or adjustments of the cointegrated variables towards their equilibrium values is employed.

The short-run dynamic of the long-run stock price index function is analyzed by computing an error-correction model (VECM) with 2 lags length. The error correction term capture the speed of the short run adjustment towards the long run equilibrium. The result shows a correct sign (negative) meaningful but insignificant. Therefore there is no short-run adjustment towards the long run equilibrium when LNSET is the dependent variable. However LNM1(-1) or one period lag of narrow money and LNREPO(-1) or one period lag of interest rate appear to have significant short term effect on LNSET where LM(-1) has a positive effect and LNREPO (-1) has a negative effect. 
Table 8. Vector error correction model estimation

\begin{tabular}{|c|c|c|c|c|c|}
\hline Error Correction: & $\mathrm{D}($ LNSET $)$ & $\mathrm{D}(\mathrm{LNCPI})$ & D(LNFOREX) & D(LNM1) & D(LNREPO) \\
\hline \multirow[t]{2}{*}{ CointEq1 } & -0.019086 & $-0.00642 * * *$ & -0.007199 & $0.055898 * * *$ & 0.152998 \\
\hline & {$[-0.53800]$} & {$[-2.83281]$} & {$[-0.93609]$} & {$[3.67821]$} & [ 4.34906] \\
\hline \multirow[t]{2}{*}{ D(LNSET(-1)) } & 0.063023 & $0.016740 * * *$ & $-0.044778 * *$ & -0.063904 & $-0.179628 *$ \\
\hline & {$[0.64691]$} & [2.68972] & [-2.12014] & {$[-1.53121]$} & [-1.85932] \\
\hline \multirow[t]{2}{*}{$\mathrm{D}(\operatorname{LNSET}(-2))$} & 0.063001 & $0.011666^{*}$ & -0.012062 & -0.052547 & -0.075422 \\
\hline & {$[0.66306]$} & [ 1.92197$]$ & {$[-0.58557]$} & {$[-1.29098]$} & {$[-0.80046]$} \\
\hline \multirow[t]{2}{*}{$\mathrm{D}(\mathrm{LNCPI}(-1))$} & -0.208725 & $0.341522 * * *$ & 0.249221 & -0.416355 & $2.345731^{*}$ \\
\hline & {$[-0.17233]$} & [ 4.41391] & [ 0.94917] & {$[-0.80246]$} & [ 1.95304] \\
\hline \multirow[t]{2}{*}{ D(LNCPI(-2)) } & 1.587143 & 0.078753 & 0.219528 & $-1.075451 * *$ & 1.741264 \\
\hline & {$[1.25613]$} & {$[0.97565]$} & [ 0.80144] & {$[-1.98689]$} & [ 1.38970$]$ \\
\hline \multirow[t]{2}{*}{ D(LNFOREX(-1)) } & 0.317491 & $0.059594 * *$ & 0.039199 & -0.273261 & -0.680678 \\
\hline & {$[0.72056]$} & [2.11713] & {$[0.41036]$} & {$[-1.44770]$} & {$[-1.55781]$} \\
\hline \multirow[t]{2}{*}{ D(LNFOREX(-2)) } & 0.030735 & -0.021197 & 0.055473 & $-0.41479 * *$ & -0.108233 \\
\hline & {$[0.07271]$} & {$[-0.78490]$} & {$[0.60530]$} & {$[-2.29047]$} & {$[-0.25818]$} \\
\hline \multirow[t]{2}{*}{ D(LNM1(-1)) } & $0.428967 * *$ & 0.010778 & -0.031287 & $-0.168191 * *$ & 0.080789 \\
\hline & [ 2.22672] & {$[0.87573]$} & {$[-0.74914]$} & {$[-2.03802]$} & [ 0.42289] \\
\hline \multirow[t]{2}{*}{$\mathrm{D}(\mathrm{LNM} 1(-2))$} & -0.277102 & 0.002885 & -0.023935 & 0.027688 & 0.101951 \\
\hline & {$[-1.44086]$} & {$[0.23480]$} & {$[-0.57409]$} & {$[0.33608]$} & [ 0.53458$]$ \\
\hline \multirow[t]{2}{*}{ D(LNREPO(-1)) } & $-0.163185 * *$ & 0.004412 & 0.003322 & -0.013318 & $0.201372 * * *$ \\
\hline & {$[-2.17130]$} & [ 0.91892] & [ 0.20391] & {$[-0.41365]$} & [ 2.70193] \\
\hline \multirow[t]{2}{*}{ D(LNREPO(-2)) } & 0.002807 & -0.00114 & $-0.026976^{*}$ & -0.012219 & 0.067808 \\
\hline & {$[0.03841]$} & {$[-0.24429]$} & {$[-1.70299]$} & {$[-0.39037]$} & [ 0.93583$]$ \\
\hline \multirow[t]{2}{*}{$\mathrm{C}$} & 0.003325 & $0.000969 * *$ & -0.001288 & $0.011905 * * *$ & -0.008574 \\
\hline & {$[0.46938]$} & [ 2.14207] & {$[-0.83901]$} & [ 3.92336$]$ & {$[-1.22054]$} \\
\hline R-squared & 0.111452 & 0.236454 & 0.101222 & 0.165281 & 0.320934 \\
\hline D-W statistic & 1.971652 & 2.037256 & 1.986708 & 1.92969 & 2.040295 \\
\hline
\end{tabular}

\subsection{Block Exogeneity Test}

According to the Granger Representation Theorem, if two or more time-series are cointergated then there must be Granger causality between them either one-way or in both directions. Since this study is under multivariate framework, the top down approach, Block exogeneity test is employed. The result in Table 9 shows that there are bidirectional causality between LNSET and LNCPI, and also between LNM1 and LNSET which is in line with Wongbangpo and Sharma (2002) study result that was conducted before the Asian economic crisis and the exchange rate switching regime from fixed to float in Thailand. The unidirectional causality is found from LNFOREX to LNSET and from LNREPO to LNSET which is also in line with Wongbangpo and Sharma (2002), and Jiranyakul (2012). 
Table 9. VEC granger causality test (Block exogeneity test)

\begin{tabular}{lllllll}
\hline \multirow{2}{*}{$\begin{array}{c}\text { Dependent } \\
\text { variables }\end{array}$} & \multicolumn{7}{c}{ Independent variables } \\
\cline { 2 - 7 } LNSET & LNSET & LNCPI & LNFOREX & LNM1 & LNREPO & ALL \\
& & 1.638237 & 0.522956 & $10.11003^{* *}$ & 5.134325 & $17.39404^{* *}$ \\
\multirow{2}{*}{ LNCPI } & $(0.4408)$ & $(0.7699)$ & $(0.0064)$ & $(0.0768)$ & $(0.0263)$ \\
& $9.333299^{* *}$ & & $5.152297^{*}$ & 0.769104 & 0.845631 & $16.34008^{* *}$ \\
\multirow{2}{*}{ LNFOREX } & $(0.0094)$ & & $(0.0761)$ & $(0.6808)$ & $(0.6552)$ & $(0.0378)$ \\
& 4.533474 & 2.269492 & & 0.68624 & 3.006377 & 11.28836 \\
LNM1 & $(0.1036)$ & $(0.3215)$ & & $(0.7096)$ & $(0.2224)$ & $(0.1859)$ \\
& 3.395256 & $6.271297^{* *}$ & $7.238712^{* *}$ & & 0.463385 & $13.9746^{*}$ \\
LNREPO & $(0.1831)$ & $(0.0435)$ & $(0.0268)$ & & $(0.7932)$ & $(0.0824)$ \\
& 3.672343 & $8.364687^{* *}$ & 2.481299 & 0.356673 & & 12.35824 \\
\hline
\end{tabular}

Note: $* * *, * *, *$ significant at level $1 \%, 5 \%, 10 \%$, respectively.

Table 10. Summary of causal relationship between stock price and monetary

\begin{tabular}{cccc}
\hline LNCPI $\rightarrow$ LNSET & LNFOREX $\rightarrow$ LNSET & LNM1 $\rightarrow$ LNSET & LNREPO $\rightarrow$ LNSET \\
\hline Yes & Yes & Yes & Yes \\
\hline LNSET $\rightarrow$ LNCPI & LNSET $\rightarrow$ LNFOREX & LNSET $\rightarrow$ LNM1 & LNSET $\rightarrow$ LNREPO \\
\hline Yes & No & Yes & No \\
\hline
\end{tabular}

\subsection{Variance Decomposition Analysis}

Variance decomposition results based on VECM are presented in Table 11. At both short and long period, the variance in stock price is mainly attributed to stock price itself. The monetary variable that contribute the highest in stock price is LNM1 in the short period and long period (2, 8 and 10 month) while the LNREPO give the highest contribution in the medium term period (4, 6 and 8 month). The variance in stock price gives the highest contribution to exchange rate $(36-53 \%)$, followed by the narrow money $(3-10 \%)$ and inflation (3-6\%) respectively. These contributions ascend when horizon increase.

Table 11. Variance decomposition analysis

\begin{tabular}{lllccc}
\hline \multicolumn{5}{c}{ Variance Decomposition of SET } \\
\hline Period & LNSET & LNCPI & LNFOREX & LNM1 & LNREPO \\
2 & 96.7167 & 0.084062 & 0.118854 & 2.022085 & 1.058324 \\
4 & 96.1667 & 0.090055 & 0.094771 & 1.5783 & 2.070219 \\
6 & 95.5227 & 0.295405 & 0.101158 & 1.862719 & 2.218009 \\
8 & 94.8113 & 0.695436 & 0.236878 & 2.14289 & 2.113462 \\
10 & 94.2714 & 1.074778 & 0.369082 & 2.298098 & 1.986612 \\
\hline \multicolumn{5}{c}{ Variance Decomposition of LNCPI } \\
\hline Period & LNSET & LNCPI & LNFOREX & LNM1 & LNREPO \\
2 & 0.6159 & 97.42791 & 0.283265 & 1.194328 & 0.478593 \\
4 & 3.71211 & 90.88829 & 0.360152 & 4.180233 & 0.859211 \\
6 & 5.37947 & 85.04096 & 1.588703 & 6.62009 & 1.37078 \\
8 & 6.08342 & 80.61569 & 3.074767 & 8.227752 & 1.998364 \\
10 & 6.38765 & 77.89458 & 4.114997 & 9.082357 & 2.52042 \\
\hline
\end{tabular}


Table 11. (continue)

\begin{tabular}{|c|c|c|c|c|c|}
\hline \multicolumn{6}{|c|}{ Variance Decomposition of LNM1 } \\
\hline Period & LNSET & LNCPI & LNFOREX & LNM1 & LNREPO \\
\hline 2 & 3.13784 & 0.095161 & 0.011411 & 96.20811 & 0.547478 \\
\hline 4 & 5.46935 & 0.840986 & 0.30292 & 90.26102 & 3.125727 \\
\hline 6 & 7.49596 & 0.699559 & 1.476881 & 83.70472 & 6.622881 \\
\hline 8 & 8.94315 & 0.729707 & 3.493222 & 76.88437 & 9.949551 \\
\hline 10 & 9.97098 & 0.834667 & 4.817777 & 72.11426 & 12.26231 \\
\hline \multicolumn{6}{|c|}{ Variance Decomposition of LNFOREX } \\
\hline Period & LNSET & LNCPI & LNFOREX & LNM1 & LNREPO \\
\hline 2 & 36.8156 & 0.124079 & 62.99573 & 0.02563 & 0.039008 \\
\hline 4 & 44.4713 & 0.50636 & 54.89437 & 0.095397 & 0.032562 \\
\hline 6 & 48.5732 & 0.384126 & 50.86664 & 0.129836 & 0.046234 \\
\hline 8 & 51.7714 & 0.303213 & 47.63368 & 0.181413 & 0.110262 \\
\hline 10 & 53.9744 & 0.276906 & 45.37531 & 0.19599 & 0.177382 \\
\hline
\end{tabular}

\subsection{Impulse Response Function Analysis}

The impulse response analysis for the horizon of 10 month indicates the response of the stock price to a one standard deviation shock to all monetary variables and vice versa are presented in figure 1 and 2.

The impulse response analysis for the response of the stock price to a one standard deviation shock to monetary variable shows that the stock price appears to be sensitive to shocks itself as well as from monetary variables. Stock price response positively to the shock of itself immediately then decline dramatically but it does not return to its baseline within 10 month horizon. For the monetary variables, stock price response intensively to LNM1 and LNREPO while LNCPI and LNFOREX produce less response. The stock price response to the shock from LNCPI and LNREPO negatively while to the shock from LNM1 and LNFOREX positively. All response do not appear to return to their baseline along the horizon.
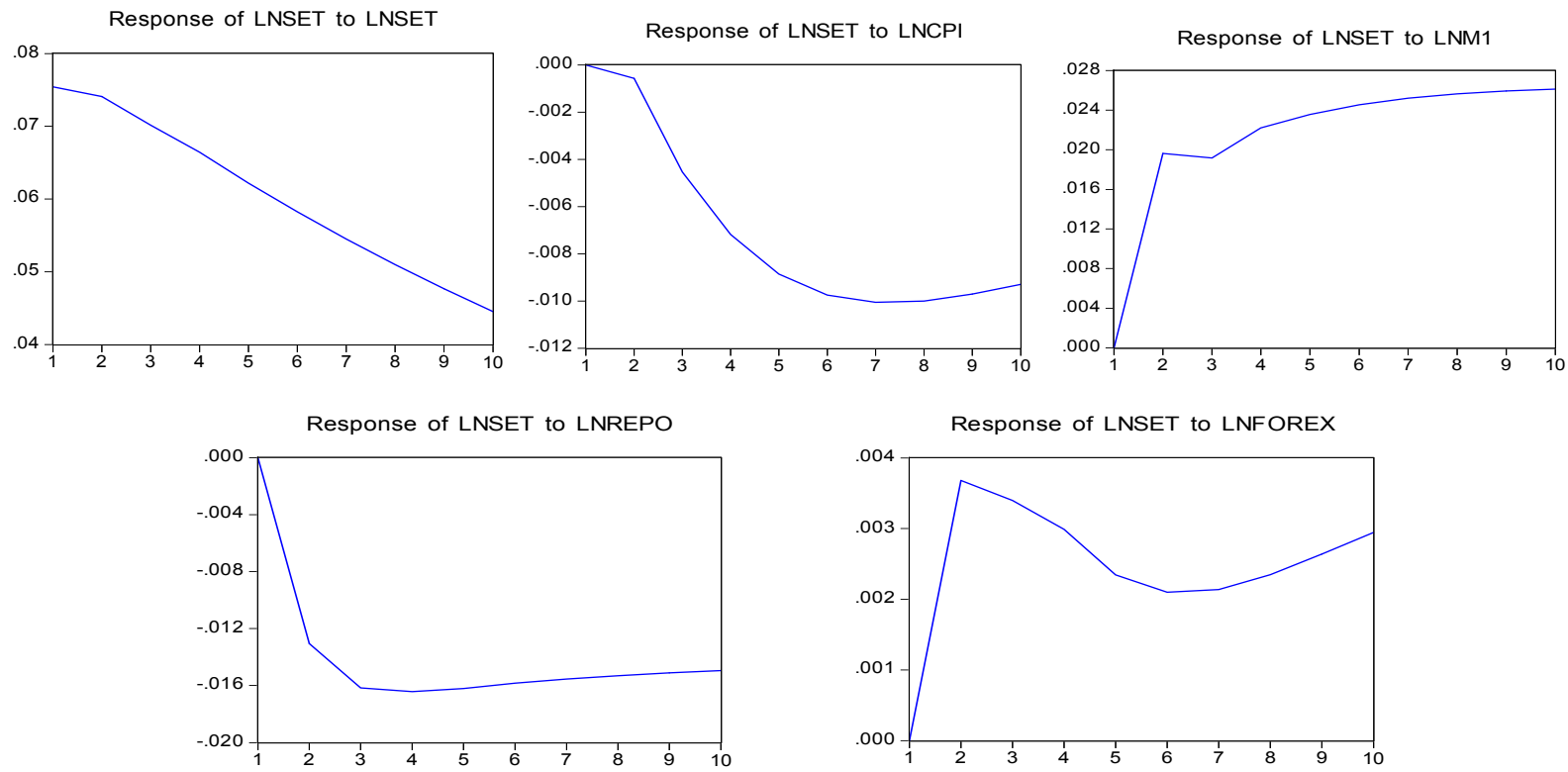

Figure 1. The impulse response analysis for the horizon of 10 months indicate the response of the stock price to a one standard deviation shock to all monetary Figure title (This is an example of Figure 1)

Description: Response to Cholesky One S.D. Innovations 
The impulse response analysis for the response of the monetary variables to a one standard deviation shock to stock price shows that all monetary variable response to the shock in stock price intensively after 2 month. LNM1, LNREPO and LNFOREX response immediately after a shock in stock price then after 2 month surge with a tremendous response and remain substantial in the long run. The response of LNCPI gradually increase over horizon and do not appear to return to its baseline again. However, it is found that LNREPO which response negatively immediately did return to its baseline within 3 months, but continue to surge with positive response after that and appear to divert away along the horizon.

The results of impulse response function analysis confirm the Vector Error Correction Model (VECM) estimation that there is no short-run adjustment towards the long run equilibrium.
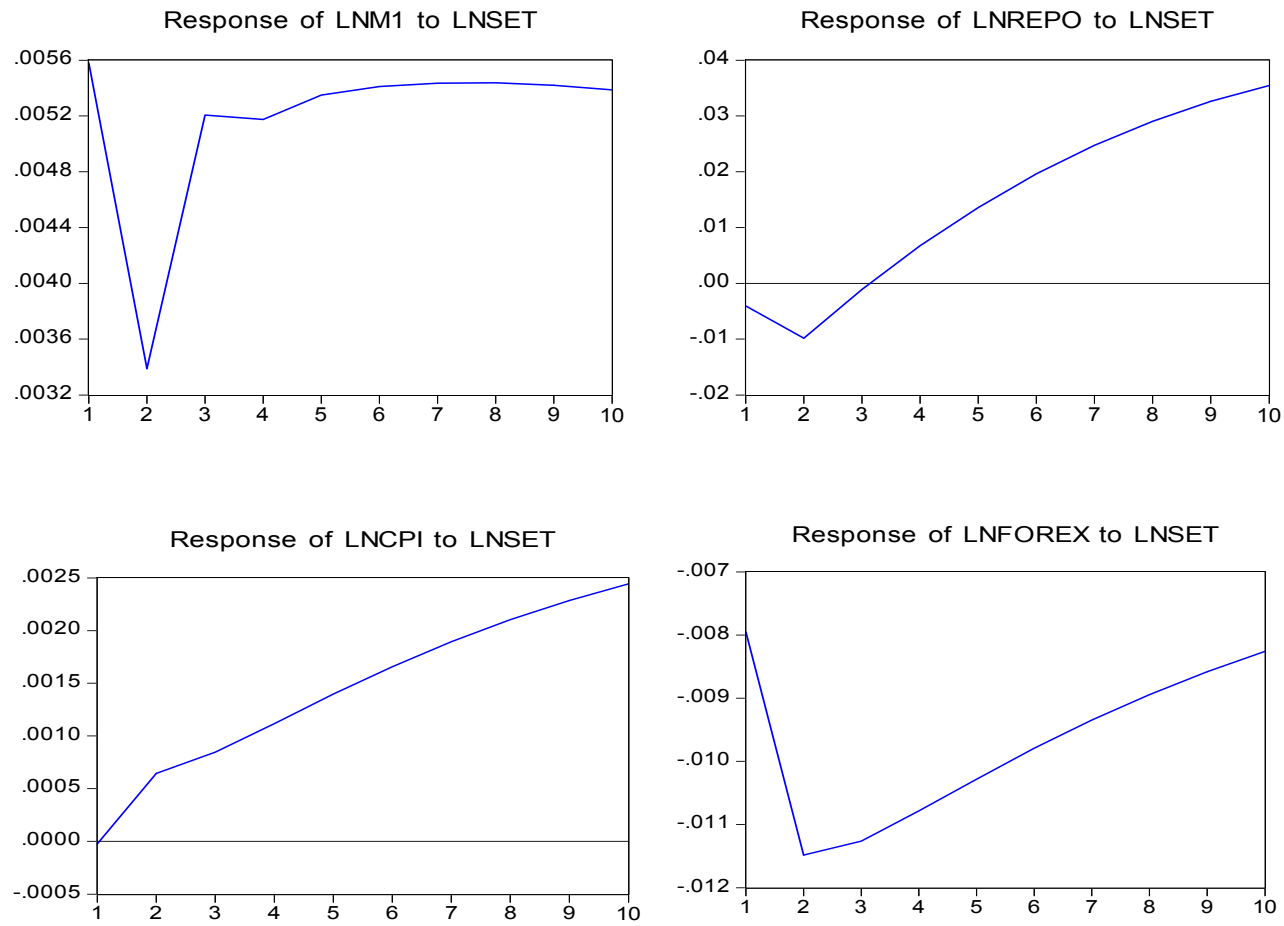

Figure 2. The impulse response analysis for the horizon of 10 months indicate the response of the monetary variables to a one standard deviation shock to stock price

Description: Response to Cholesky One S.D. Innovations

\section{Discussion}

This paper examines the relationship between stock price and monetary variables in Thailand which is an Asian small open emerging economy employing a multivariate cointegration, VECM, variance decomposition and impulse response analysis covering the period of January 1999 to December 2012 with 168 observations.

Most studies focus on developed economies, this paper provides an example of the relationship of monetary variables and stock price in an Asian small open emerging economy by evaluating the notion that monetary variables contain information to forecast stock price using multivariate framework. The multivariate cointegration analysis indicates that there exist a long run relationship between monetary variables and stock price in Thailand. However, the Vector Error Correction Model (VECM) with 2 lags length analysis found no short-run adjustment towards the long run equilibrium. One period lag of narrow money and interest rate have a short run effect on stock price. The causality test indicate a bidirectional causality between stock price and consumer price index, and also between narrow money and stock price. The unidirectional causality is found from exchange rate to stock price and from interest rate to stock price. Variance decomposition results indicate the monetary variable that contribute the highest in stock price is narrow money in the short period and long period (2, 8 and 10 month) while the interest rate give the highest contribution in the medium term period (4,6 and 8 month). The variance in stock price that mainly attributed to the monetary variables are the exchange rate (36-53\%), narrow money (3-10\%) and consumer price index (3-6\%). These contributions ascend when horizon increase.

The impulse response analysis for the response of the stock price to a one standard deviation shock to monetary 
variable shows that the stock price appears to be sensitive to shocks itself as well as from monetary variable. Stock price response intensively to narrow money and interest rate while consumer price index and exchange rate produce less response. For the response of the monetary variables to a one standard deviation shock to stock price shows that all monetary variable response to the shock in stock price intensively after 2 months and all of response appear to divert away along the horizon which confirm the result from the Vector Error Correction Model (VECM) analysis that there is no short-run adjustment towards the long run equilibrium.

The study result supports the notion that monetary variables contain information to forecast stock price especially narrow money and interest rate which contribute the highest in stock price both in the short period and long period. However, it also suggests that stock price also contain information to forecast monetary variables such as exchange rate, narrow money and consumer price index. The clear picture of relationship facilitates investor and policy maker in making effective investment decision as well as the efficient policy designation in Asian small open emerging economy by taking these monetary variables into account. A change in monetary variable is a signal for a change in stock price and a change in stock price is also a signal for a change in monetary variable in the next two months. The evidence offers a useful insight to investors to revise investment decision as well as to the policy makers in forecasting real economic activity.

\section{References}

Binswanger, M. (2003). Stock returns and real activity in the G-7 countries: did the relationship change during the 1980s? The Quarterly Review of Economics and Finance, 44, 237-252. http://dx.doi.org/10.1016/j.qref.2003.07.001

Cheung, Yin-Wong, \& Ng, L.K. (1998). International evidence on the stock market and aggregate economic Activity. Journal of Empirical Finance, 5, 281-296.

Chokesirikulchai, A., Ngamkroeckjoti, C., \& Chuanrommanee W. (2013). Comparison between SET index and SET Property Development Index Based on Macroeonomic Factors in Thailand during 2001-11. The 2013 IBEA International Conference on Business, Economics, and Accounting 20-23 March 2013, Bangkok, Thailand.

Garza-Garcia, J.G., \& Yue, Y. (2010). International Determinants of stock market performance in China: a cointegration approach. Working Paper in Centre for Global Finance, University of the West of England, 03/10.

Granger, C.W.J. (1988). Some recent development in a concept of causality. Journal of Econometric, 39, 199-211. http://dx.doi.org/10.1016/0304-4076(88)90045-0

Habibullah, M.S., \& Baharumshah, A.Z. (1996). Money, output and stock prices in Malaysia: an application of the cointegration tests. International Economic Journal, 10(2), 121-130.

Herve, D.B.G., Chanmalai, B., \& Shen, Y. (2011). The study of causal relationship between stock market indices and macroeconomic variable in Cote d' Ivoire: evidence from error-correction models and Granger causality test. International Journal of Business and Management, 6(12), 146-169. http://dx.doi.org/10.5539/ijbm.v6n12p146

Hosseini, S.M., Ahmad, Z., \& Lai, Y.W. (2011). The role of macroeconomic variables on stock market index in China and India. International Journal of Economics and Finance, 3(6), 233-243. http://dx.doi.org/10.5539/ijef.v3n6p233

Janor, H., Halid, N., \& Rahman, A.A. (2005). Stock market and economic activity in Malaysia. Investment Management and Financial Innovation, 4, 116-123.

Jiranyakul, K. (2012). Linkages between Thai stock and foreign exchange markets under the floating regime. Journal of Financial Economic Policy, 4(4), 305-319. http://dx.doi.org/10.1108/17576381211279280

Mansor H. Ibrahim, Jaharudin Padli, \& A. H. Baharom (2009). Long-run relationships and dynamic interactions between housing and stock prices in Thailand. Asian Academy of Management Journal of Accounting and Finance, 5(1), 93-105.

Mitchell, J. (2000). The importance of long run structure for impulse response analysis in VAR models. Working paper in National Institute of Economic and Social Research, Online-Resource, 23, text; ill

Sim, K.T., \& Maysami, R.C. (2000). A cointegration analysis of the impact of economics forces and global market integration on the Singapore stock market. Nanyang Technological University, Singapore.

Tangjitprom, N. (2011). Macroeconomic factors of emerging stock market: the evidence from Thailand. International Journal of Financial Research, 3(2), 105-114.

Wongbangpo, P., \& Sharma, S.C. (2002). Stock market and macroeconomic fundamental dynamic interaction: ASEAN-5 countries. Journal of Asian Economics, 13, 27-51. http://dx.doi.org/10.1016/S1049-0078(01)00111-7

\section{Note}

Note 1. Mitchell (2000). 